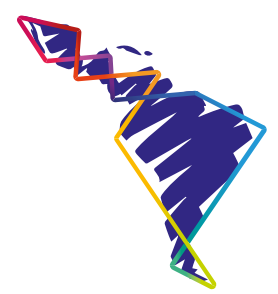

\title{
El primer brote: origen del humanismo
}

\section{The first outbreak: origin of humanism}

\section{0 primeiro surto: origem do humanismo}

\author{
Miguel David Baraona Cockerell ${ }^{1}$
}

Soy hombre, nada humano me es ajeno.

Publio Terencio Africano (a. C. -159 a. C.)

El hombre es la medida de todas las cosas.

Protágoras (486 a. C. -411 a. C.)

Este cosmos, el mismo para todos, no ha sido creado ni por los dioses ni por los hombres, sino que siempre fue, es y será fuego viviente, que se enciende según medida y se extingue según medida. Heráclito (540 a. C. -480 a. C.)

¿Por qué la infancia histórica de la humanidad, en el momento más bello de su desarrollo, no debería ejercer un encanto eterno, como una fase que no volverá jamás? Hay niños mal educados y niños precoces. Muchos pueblos antiguos pertenecen a esta categoría. Los griegos eran niños normales. El encanto que encontramos en su arte no está en contradicción con el débil desarrollo de la sociedad en la que maduró. Es más bien su resultado.

Marx (1818-1883)

\section{Resumen}

En el siglo V a. C. surgió en Atenas y, luego se extendió a casi toda la Grecia antigua, un movimiento ético-filosófico con fuerte orientación a la filosofía política, que se conoce como

1 El autor es chileno. Actualmente se desempeña como académico del Centro de Estudios Generales de la Universidad Nacional, Costa Rica. Obtuvo un doctorado en Antropología Social de la Universidad de Texas en Austin, Estados Unidos y una maestría y licenciatura en sociología en la EHESS y en La Sorbona en París. ORCID: https://orcid.org/0000-0003-1609-3929 Correo electrónico: miguel.baraona.cockerell@una.cr 
sofismo y/o sofistería. Las dos figuras más prominentes del sofismo serían, Protágoras en el ámbito intelectual, y Pericles en el político. Pero un amplio grupo de otros filósofos, harían del sofismo la más grande revolución intelectual presocrática en la Grecia clásica. Estos pensadores progresistas impulsarían la democracia representativa, a niveles que después no se conocerían en el mundo antiguo. Y esto llevaría a reformas sociales propias de un Estado benefactor, como queda consignado en la Constitución que Protágoras redactó para la nueva colonia de Turios. Pero lo más trascendente es que el sofismo sentó las bases para la muy audaz idea, en aquellos tiempos, de que el ser humano (bajo la forma del ciudadano común) es el único protagonista en escoger y forjar su destino individual y colectivo, aunque no se alcance a plenitud y en la forma deseada. Este giro radical, colocando al ser humano en el centro mismo de su propio destino, y al margen de fuerzas omnímodas de orden divino y sobrenatural, es lo que en el Renacimiento europeo, siglos después, se llamaría humanismo. Y el corolario principal que se deriva de esta premisa, es que el ser humano es, por antonomasia, el forjador de su propia liberación por medio de su razón y voluntad. Es decir: protagonista fundamental de su auto-emancipación.

Palabras claves: Humanismo, Grecia clásica, Protágoras, sofistas

\begin{abstract}
In the 5th century BC arose in Athens and then spread to almost all of ancient Greece, an ethical-philosophical movement with a strong orientation to political philosophy, which is known as sophism and/or sophistry. The two most prominent figures of sophism would be, Protagoras in the intellectual field, and Pericles in the political field. But a large group of other philosophers would make sophism the greatest pre-Socratic intellectual revolution in classical Greece. These progressive philosophers would push for representative democracy, to levels that would later not be known in the ancient world. And this would lead to social reforms typical of a welfare State, as consigned in the Constitution that Protagoras drafted for the new colony of Thurios. But the most important aspect is that sophism laid the foundations for the very audacious idea in those times, that the human being (in the form of the common citizen) is the only protagonist in choosing and forging his individual and collective destiny, even though destiny may not be achieved fully and in the desired manner. This radical turn, placing the human being at the very center of his own destiny, and outside the ominous forces of divine and supernatural order, is what in the European Renaissance, centuries later, would be called humanism. The main corollary derived from this premise is that the human being is, par excellence, the forger of his own liberation through his reason and will. That is to say: the fundamental protagonist of his self-emancipation.
\end{abstract}

Keywords: Humanism; Classical Greece; Protagoras; Sophists.

\title{
Resumo
}

No século $5 \mathrm{aC}$ surgiu em Atenas e se espalhou por quase toda a Grécia antiga, um movimento ético-filosófico com forte orientação para a filosofia política, que é conhecido como sofisma e / ou sofisma. As duas figuras mais proeminentes do sofisma seriam, Protágoras no campo intelectual e Péricles no campo político. Mas um grande grupo de outros filósofos faria do sofisma 
a maior revolução intelectual pré-socrática da Grécia clássica. Esses filósofos progressistas pressionariam por democracia representativa, em níveis que mais tarde não seriam conhecidos no mundo antigo. E isso levaria a reformas sociais típicas de um estado de bem-estar, como afirma a Constituição que Protágoras elaborou para a nova colônia de Turios. Mas o mais importante é que o sofisma lançou as bases para a ideia muito audaciosa daqueles tempos, de que o ser humano (na forma de cidadão comum) é o único protagonista na escolha e construção do seu destino individual e coletivo, embora não é alcançado totalmente e na forma desejada. Essa virada radical, colocando o ser humano no centro de seu próprio destino, e fora das forças onimosas da ordem divina e sobrenatural, é o que na Renascença europeia, séculos depois, seria chamado de humanismo. E o principal corolário que deriva dessa premissa é que o ser humano é, por excelência, o falsificador de sua própria libertação por meio de sua razão e de sua vontade. Ou seja: um protagonista fundamental de sua auto-emancipação.

Palavras-chave: Humanismo; Grécia clássica; Protágoras; Sofistas.

\section{Introducción: retórica y realidad del humanismo}

Haciendo referencia a la famosa frase de Publio Terencio que citamos como apertura a este trabajo, Miguel de Unamuno (1864-1936) hizo la siguiente reflexión:

Homo sum, nihil humani a me alienum puto dijo el cómico latino. Y yo diría más bien, nullum hominem a me alienum puto; soy hombre, a ningún hombre estimo extraño. Porque el adjetivo humanus me es tan sospechoso como su sustantivo abstracto humanitas, la humanidad. Ni lo humano ni la humanidad, ni el adjetivo simple ni el sustantivado, sino el sustantivo concreto: el hombre. (Unamuno, 1979: p. 33)

Este planteamiento de Unamuno nos lleva, en efecto, al corazón mismo del tema del humanismo, pues pone de manifiesto ese tránsito tan radical y revolucionario que los filósofos sofistas, y en especial Protágoras, iniciaran hace alrededor de dos mil quinientos años atrás en la Grecia clásica de Pericles (495 a. C. -429 a. C.). Lisa y llanamente, lo que el escritor sugiere aquí, es que el ser humano no debiera ser tema de disquisiciones filosóficas abstractas, y de alambicadas generalizaciones con presunción de universalidad metafísica sobre una supuesta "esencia humana" atemporal y eterna, sino el sujeto de indagación y reflexión sobre el hombre concreto, de carne y hueso, biológico y social, lo que responde a su naturaleza intrínseca como entidad animal y social, expresándose en infinidad de posibilidades y contextos históricos e incluso naturales. Pero Unamuno era un hombre de su tiempo, y aún su genio indiscutible, sufrió por las obvias limitaciones que el conocimiento sobre nuestra especie tenía en aquella época. De modo que su aproximación antropológica a un hombre concreto y específico, estaba motivada por todas las razones intelectuales correctas, pero en sus textos esta visión no pasó de ser también de índole meramente conjetural, a-biológica, a-histórica, y por 
ende, solo especulativa. Y, sin dudas, en ello influyó, además, un poderoso sesgo intelectual e individual (Fernández, 2017), propenso a una tradición filosófica basada en presuposiciones hipotéticas y con rechazo a lo que él mismo llamaba "cientificismo" (Gutiérrez, 1999).

Es allí donde, a mi juicio, fracasa Unamuno en darnos una aproximación realista al "hombre concreto", pero mucho antes que él, otro admirador de la frase de Publio Terencio, fundador de la única propuesta sistémica, interdisciplinaria y holística sobre el ser humano y su vida social, unía su visión científica del devenir humano al fundamento emancipador y prometeico del humanismo, cristalizado en lo que sus fundadores llamaron socialismo cientifico.

El día $1 .^{\circ}$ de abril de 1865 , mientras estaba en Holanda con su tío Lion Philips, Marx completó un cuestionario que era un pasatiempo común de tipo familiar en la era victoriana, sobre algunos de sus gustos y desagrados principales. Y decidió responder en la pregunta sobre su máxima favorita, escogiendo la misma que Unamuno suscribiera y comentara con tanto entusiasmo: Nihil humani a me alienum puto (Blunden, 1956). Con posterioridad, su hija Jenny conservaría ese cuestionario con las respuestas escritas a mano por el propio Marx, en su diario de vida.

Nos hemos detenido en este último evento, en apariencia trivial, puesto que esa máxima escogida por Marx, en efecto, pone de manifiesto en una diminuta cápsula filosófica, su total y plena identificación con la propuesta humanista de aquellos filósofos griegos que siglos antes la formularan con todos sus rasgos esenciales, ${ }^{2} \mathrm{y}$ que perduran incólumes hasta nuestros días. Y, de esa perspectiva y su persistencia en el tiempo durante dos mil quinientos años, a lo largo de cinco avatares históricos principales, es lo que constituye el núcleo esencial de este ensayo.

Deseamos aquí enfilar hacia la definición más precisa, más sintética, y que se apoya en el vasto expediente histórico en la praxis (combinación de teoría y práctica) humanista misma, y no en clichés reconfortantes, almibarados sortilegios retóricos, y presuntuosas fantasías que poco o nada tienen que ver con el origen, la génesis, el impacto, y las vicisitudes de una idea tan simple como portentosa: el ser humano como gestor de su propio destino, y, asumiendo, queriéndolo o no, las consecuencias y la responsabilidad ineludible de sus propias aspiraciones y acciones individuales o colectivas; el ser humano, persiguiendo y prosiguiendo su auto-emancipación, y fracasando o triunfando en el intento, ${ }^{3}$ al ejercer de manera consciente su poder de razonamiento y su voluntad para tratar de alcanzar sus deseos y aspiraciones.

2 Y que fuese magistralmente sintetizada por la famosa frase del comediante y dramaturgo bereber-romano y exesclavo, Publio Terencio Africano, siglos después de la sofistería.

3 O una combinación de ambas. 
Este ensayo constituye el primero de una serie en que expondremos sobre el nacimiento, los avatares históricos, las enormes consecuencias derivadas o asociadas a la revolución humanista a lo largo de dos mil quinientos años, y que han permitido los avances más progresistas y benéficos para el desarrollo de la humanidad hacia expectativas y logros tangibles en términos de justicia social, equidad, libertad, y el conocimiento racional y científico del mundo natural y de la misma naturaleza humana.

\section{Orígenes: el gran giro humanista}

En otros trabajos sobre el gran tema del humanismo, hemos escrito algo sobre los orígenes del postulado humanista en la Grecia de Pericles (Baraona y Mora, 2017) (Baraona, 2013). De modo que en esta producción nos detendremos mucho más en el parto luminoso, sin el cual hoy no tendríamos ciencia, ni derechos humanos, ni democracia, ni socialismo, sino que viviríamos aún sumidos en las tinieblas de la superchería y librados, en nuestra mente colectiva, al arbitrio de fuerzas y poderes sobrenaturales, al concebir nuestras terribles desigualdades como fruto de algún implacable mandato divino, o como producto de "diferencias naturales". ${ }^{4}$

Lo más sorprendente de este gran giro humanista, es que lo impulsan un grupo de filósofos pre-socráticos, de mucho menor reconocimiento intelectual que los grandes que vendrían poco tiempo después (Romilly, 1997), como Sócrates (470 a. C. -399 a. C.), Platón (427 a. C. -347 a. C.) y Aristóteles (384 a. C. -322 a. C.). Y de esta escuela sofista de filosofía, el más importante por mucho sería Protágoras de Abdera (485 a. C. -411 a. C.). Otros sofistas destacados fueron Gorgias (485 a. C. -380 a. C.), Licofrón (siglo III a. C.), Pródico (465- a. C. -395 a. C.), Trasímaco (459 a. C. -400 a. C.), Hipias (i? a. C.-490 a. C.), Antifonte (480 a. C. -411 a. C.), Fidias (500 a. C. -431 a. C.), Eurípides (480 a. C. -406 a. C.), Sófocles (490 a. C. -406 a. C.), Pericles (495 a. C. -429 a. C.), Tucídides (460 a. C. - c. ¿396 a. C.?).

Dejaremos de lado la propuesta filosófica de Protágoras conocida como relativista y escéptica, pues negaba la existencia de leyes generales y universales, y de verdades absolutas, y proponía que, toda interpretación de la realidad contenía, en sí misma, su verdad parcializada pero legítima, moldeada por las palabras y por la escogencia de las narrativas y modalidades lingüísticas, y que, en esos términos tan subjetivos, tenía pues su propia validez. Y si bien esta postura parece negar la posibilidad del conocimiento científico basado en leyes universales (ley de la gravitación universal, e irónicamente, la ley de la relatividad); lo cierto es que el escepticismo ante toda presunción metafísica y totalizante, pareciera, por otro lado, estar en acorde con la cautela propia de la ciencia moderna. Podríamos decir que este énfasis en

4 Como postularía el propio Aristóteles. 
las formas idiomáticas, que envuelven y dan sentido a cada interpretación de la realidad, y al hacerlo la tornan relativa e ininteligible en términos universales, se encuentra prefigurada de un modo aún lejano, mucho de la perspectiva que hoy conocemos como posmodernista. Y a la que Platón dedicó tanta energía y pasión en su esfuerzo para desbancar filosóficamente a los sofistas. Aunque no nos alineamos con las poderosas diatribas de Platón en contra de los sofistas, a quienes de algún modo parece caracterizar como una caterva de charlatanes a sueldo, si aceptamos que los métodos probatorios que estos últimos empleaban, a menudo, para imponer su "criterio de verdad", rayaban en lo absurdo y la simple manipulación retórica, y de allí que el empleo de los adjetivos como sofisma y sofistería sean utilizados casi siempre en términos peyorativos. Y así, sofisma pasa a ser equivalente con argumentos mañosos y rebuscados para defender una idea o conocimiento sobre todo falso; es retórica astuta y manipuladora para convencer a toda costa mediante un discurso tan elegante como vacuo.

En la inquina de Platón hacia los sofistas, podemos también discernir el desprecio del filósofo elitista que soñaba con un Estado que funcionara como una suerte de "dictadura benigna de filósofos y sabios", versus las nociones más "populistas", igualitarias y democráticas de los sofistas. Y además, Platón era intelectualmente un buen reflejo de la restauración conservadora que sustituyó en Atenas al período progresista y liberal de Pericles. Y estando en desacuerdo con esta postura relativista a ultranza, y viendo en ella poca o ninguna conexión con el tema del humanismo, ${ }^{5}$ la dejaremos como un borroso trasfondo, no por escasez de interés, sino por falta de relevancia para el tópico que nos ocupa en este ensayo.

Debemos admitir, además, que la mayor parte de las percepciones y nociones que sobre la sofistica nos han llegado, en forma directa, de la Grecia clásica, provienen de los famosos diálogos platónicos. Sin embargo, como bien ha escrito Alfredo Llanos, hay que rescatar hoy en día la idea de que los sofistas eran:

[...] un grupo peculiar de intelectuales que aparecen en el ámbito cultural helénico, realizando una profunda ofensiva iluminista llamada a remover la conciencia pública hasta provocar cambios verdaderamente revolucionarios, en el modo de pensar y en las costumbres de la comunidad. (Llanos, 1953: 263)

Y según este mismo autor, hay que considerar sobre todo en la evaluación actual que podemos y deberíamos hacer de la sofistería, que:

5 Aunque estamos conscientes que podría argüirse que hay un cierto nexo entre ese relativismo filosófico a ultranza, y una cierta concepción del conocimiento como un ejercicio válido para ser ejercido por todos y todas las personas. 
[...] el movimiento sofístico, se caracteriza por la toma de conciencia del hombre frente a la historia y la sociedad y la afirmación de su tarea, que es la de dominar el saber para triunfar sobre los hechos ciegos de la naturaleza y la propia ineptitud del individuo tiranizado por la ignorancia, el hábito y la autoridad. (Llanos, 1953: 270)

Por ende, en donde el trabajo y el pensamiento de Protágoras y los sofistas se inserta directamente con el centro mismo de la praxis humanista en su nacimiento precoz en el siglo $\mathrm{V}$ a. C., es en el ámbito de lo que podríamos llamar comofilosofía política y del derecho natural.

O como muy bien señala Ricardo López Pérez:

En sus orígenes, en la antigua Grecia, el vocablo sofista se utilizó para designar a quien se mostraba experto en alguna actividad. Podía ser la filosofía, la poesía, la música o la adivinación, pero siempre un sofista era un maestro de sabiduría, alguien que se proponía hacer sabio a quien recibiera sus enseñanzas. (Ricardo López Pérez 2018: 1)

$\mathrm{Y}$ es en ese terreno de pensamiento práctico y aplicado a los asuntos de la polis y del Estado, en donde los sofistas, en general, pero sobre todo Protágoras en su estrecha amistad con Pericles, brillaron muy alto y señalaron el derrotero futuro del movimiento humanista. El humanismo nace, en lo esencial, como una praxis de restructuración revolucionaria de la sociedad, y como una reivindicación del poder de la voluntad humana para moldear una vida individual y colectiva más justa y más satisfactoria.

\section{La cuna}

Lo primero que hay que destacar en relación con esto último, es que los sofistas fueron en su enorme mayoría extranjeros en la ciudad-Estado de Atenas; y llegaron a esta última atraídos por su prosperidad, sofisticación y su esplendor intelectual, desde las colonias y sin ser ciudadanos de primera clase, por decirlo de algún modo. Atenas era ya, desde fines del siglo VI a. C. y comienzos del siglo V a. C., una metrópolis llena de vida, enriquecida y engalanada por los grandes triunfos militares contra los persas, y a ella confluían impuestos recabados en muchos lugares, y otros tesoros materiales que fluían sin cesar de toda esa constelación de colonias y territorios anexados políticamente, o incorporados al circuito económico del mundo helénico en ascenso. Y desde Asia Menor, norte de África, buena parte del Mediterráneo, y por supuesto Persia, llegaban a Atenas toda clase de riquezas que creaban en esta polis lujo, opulencia, y hay que decirlo, cierta decadencia autocomplaciente. 
La ciudad-Estado de Atenas sería crucial para el éxito en aumento de los sofistas, y sin ella su eventual hegemonía filosófica-intelectual-política habría sido inviable. Y el poderío clásico de Atenas que le permitía brillar en las esferas intelectuales, filosóficas, artísticas y política, estaba erigido sobre el señorío de su flota (misma que les permitiría prevalecer en las guerras con los persas), una moneda muy fuerte que respondía en su valor a un patrón plata, la que se producía en abundancia en las minas de Labrión, y en un sistema de impuestos efectivo, que operaba a todo lo largo y ancho del imperio. Y de esa riqueza material nacía, en parte, la espléndida generosidad con que se remuneraron las cátedras y seminarios vivientes que muchos sofistas ejercieron en Atenas y en muchas otras ciudades y territorios del imperio (Romilly, 1997). Y también de la idea cardinal en la Grecia de Pericles, que los intelectuales constituían un faro luminoso que guiaba al Estado y la ciudadanía, en general, hacia posibilidades más promisorias y más satisfactoria para todos. Sin esta ideología de Estado, ningún gran intelectual, por más brillante que fuera su pensamiento, habría podido obtener el reconocimiento e influencia que muchos lograron en este período de la Grecia antigua.

Todos los espléndidos logros de los atenienses, que iban mucho más allá de sus victorias militares en las guerras médicas, y que abarcaban la literatura y la dramaturgia, la arquitectura con el Partenón y otras obras notables, la escultura realista, la poesía, la filosofía, la navegación y el comercio, etc., nos dan una idea de grandeza, pero poco nos dicen de la sociedad y la política griega. Era una sociedad brutalmente desigual: con un promedio de doce esclavos por cada ateniense, aunque esta relación variaría, de forma considerable, en distintas épocas. La esclavitud comprendía varias categorías, desde las más expoliadas, y que han sido denominados como esclavos-mercancía, hasta aquellos que tenían ciertas prerrogativas mínimas y fungían más como siervos de la gleba (Garlan, 1989), al igual que ocurrió en toda Europa durante el feudalismo.

Entre el 317 y el 307 a. C., Demetrio de Falero (350 a. C.-282 a. C.), un dictador con pretensiones de sabiduría, organizó un censo del Ática (región del sur árido de la península Griega en el Peloponeso) solo de hombres -pues las mujeres no eran ni siquiera dignas de ser contabilizadas- el que arrojó las siguientes cifras: 22000 ciudadanos, 11000 metecos (extranjeros libres viviendo en alguna de las ciudades-Estado griegas, y era una denominación sin ribetes peyorativos) y 425 000 esclavos. Esta es una pequeña instantánea en un momento específico de la evolución de la antigua sociedad griega, pero no por ello es menos reveladora.

De otra parte, en esta sociedad con gran desigualdad de clases y estamentos sociales, regía también una terrible inequidad de género. Las mujeres de la clase alta estaban remitidas al gineceo, denominación con la que se referían los griegos antiguos al espacio 
que estaba reservado a las mujeres en las casas de las familias más acomodadas. Casi siempre el ámbito físico que segregaba a las mujeres se encontraba, en las casas más grandes, en el segundo piso, mientras que toda la planta baja estaba reservada para los hombres. Sin embargo, con el tiempo esto se modificó, y el gineceo propiamente tal, sería una gran habitación independiente en el primer piso de los hombres, pero separada del espacio de estos últimos. Este gineceo aparece en los tiempos más prósperos de la Grecia antigua, solo en aquellas casas más suntuosas, pertenecientes a las familias más ricas (Vidal-Naquet, 1995: 267-288), y las trabajadoras de los sectores más humildes, sometidas, en general, a un régimen patriarcal sin miramientos; había también un buen número de mujeres esclavas que formaban parte del botín de guerra, reducidas a la condición de concubinas, o utilizadas para ser canjeadas por algún rescate, al igual que ciertos hombres hechos prisioneros (Vidal-Naquet, 2005).

Empero, hubo mujeres de la clase alta y otras que llegaban a destacarse por sus especiales dones intelectuales (poetisas, biólogas, filósofas, etc.) y síquicos (sacerdotisas de templos conocidas como pitias), (Mossé, 1991). No podemos afirmar que sepamos exactamente cómo fue la condición de la mujer en las distintas fases históricas del mundo helenístico, pues aún hay mucho que descubrir mediante el trabajo arqueológico y la indagación histórica más pormenorizada (Pomeroy, 1999); pero lo que sí podemos aseverar, sin peligro de equivocarnos mucho, es que al igual que en muchas otras civilizaciones de la antigüedad, la vida, roles y oportunidades de las mujeres distaban mucho de ser igualitarias y satisfactorias, y, por cierto, eran muy inferiores a la de los hombres de igual o superior posición social (Pomeroy, 1990).

Y no se puede soslayar el hecho paradojal, que parece ir en contra de lo que podría imaginarse, en la rudimentaria Esparta las mujeres gozaban de mayor igualdad respecto a los hombres, que en la sofisticada Atenas. A diferencia de esta última, en Esparta las mujeres griegas (no esclavas o en servidumbre) tenían una mayor equidad con los hombres libres y ciudadanos en varios aspectos importantes: ellas, las de clase alta, podían participar en la educación, en atletismo, en las artes, y tenían igualdad ante la ley en algunos dominios como en poseer propiedades (pero no en el proceso político), y existía un posible sistema de reyes y reinas con prerrogativas simultáneas, llamado diarquía.

El trasfondo social de Grecia en la época en que Protágoras y los sofistas inician su labor filosófico-pragmática, y ejercen una ascendencia en aumento sobre la vida política y cultural helenística, es como hemos visto en las breves pinceladas anteriores, una sociedad con profundas desigualdades y asimetrías: ciudadanos y población libre (incluidos metecos) y esclavos, hombres y mujeres, y griegos y extranjeros, y, en un sentido más amplio y de carácter étnico, mundo helenístico y bárbaros, percibidos estos últimos, en su mayoría, como pueblos y culturas inferiores. 
Pero aun así, Atenas en el apogeo de su esplendor clásico, ofrece, bajo la dirección del gran estadista reformador e ilustrado que fue Pericles, un terreno de enorme fertilidad para la implantación y florecimiento de la semilla del humanismo; vale decir, del germen de la soberanía humana sobre los asuntos humanos, y no de la soberanía de las fuerzas divinas y sobrenaturales sobre el destino de nuestra especie, y del poder de la razón y la voluntad humana para trazarnos el destino que consideremos más necesario o apropiado, tanto en el nivel individual como social.

Y sin dudas, el mayor clima de libertad y tolerancia que Pericles le imprimió a su gestión y a la política ateniense en sus años de liderazgo, fue un factor muy favorable a la acción de los sofistas, quienes recibieron no solo apoyo político del estadista, sino que fueron recompensados pecuniariamente con holgura por sus asesorías en que ellos -sobre todo Protágoras, quien con el tiempo llegó a ser un hombre muy adinerado- enseñaban el arte de la retórica, orientada al conocimiento argumentativo y las habilidades pragmáticas que llevan al éxito. A pesar de la atmósfera auspiciosa que predominaba en el Estado ateniense dirigido por Pericles, subsistía aún un poderoso sustrato conservador de elevados políticos, juristas, militares, sacerdotes y hombres de fortuna, que no eran y nunca serían favorables a la sofistería y su concepción político-jurídica de corte reformista.

La afamada democracia ateniense, es en realidad una idea política igualitaria que solo concierne a los ciudadanos griegos, y dejaba fuera la enorme masa humana esclavizada, a las mujeres, e incluso a aquellos metecos que todavía no adquirían carta de ciudadanía plena en esa polis. Era una democracia representativa que estaba reservada a un grupo minoritario y privilegiado de la sociedad, pero, aun así, de enorme y magnífica trascendencia en el contexto de la época y de las civilizaciones en la antigüedad. Y en tal sentido, era una democracia muy limitada, al menos en el sentido moderno del concepto, pero lo suficientemente trascendental como para facilitar la irrupción del reformismo de Pericles y la sofistería en la sociedad ateniense del siglo $\mathrm{V}$ a. C.

Y es necesario en este punto, hacer un brevísimo paréntesis sobre el tema de la democracia ateniense, haciendo lo posible para no incurrir en una digresión excesiva.

El tema es enorme y no se agota todavía, a pesar del interés que ha despertado en toda clase de investigadores de la historia antigua. Empezaremos por señalar muy rápidamente, resaltando el hecho que Atenas sería la primera polis en Grecia y en sociedades con Estado, sistema político organizado y jerarquías de clase, ${ }^{6}$ en

6 En sociedades usualmente tribales, sin Estado, sistema político, ni clases sociales, sabemos que existían, a veces, prácticas democráticas basadas en el voto general, que incluía a mujeres junto a todos los otros adultos del grupo.

$10 \mid \begin{aligned} & \text { Revista Latinoamericana de Derechos Humanos } \\ & \text { Volumen } 32 \text { (1), I Semestre 2021 } \\ & \text { ISSN: 1659-4304 • EISSN: 2215-4221 }\end{aligned}$ 
establecer participación electoral de todos los ciudadanos (una minoría excluyente, como ya hemos señalado) con un voto por cabeza y universal, dentro del universo votante. $Y$ es a este procedimiento, lo que en esencia llamamos democracia representativa, el principio fundamental que rigió en la Grecia clásica a partir del siglo VI a. C., es aquel que con distintas modalidades se sigue aplicando hasta el día de hoy en lo que convencionalmente denominamos "democracia", o gobierno del pueblo. En el resto de Grecia hubo, en algunos momentos, diversas formas e intentos de establecer un sistema político que siguiera las pautas de Atenas, pero ninguna alcanzó los rasgos más notables de la polis antecesora. Atenas sigue destacándose en este aspecto democrático de la organización de la política, entre las civilizaciones antiguas complejas. Incluso en el marco de una sociedad bastante xenófoba, clasista, racista y sexista, pero donde, entre pares ciudadanos, se desarrollaba en forma colectiva la legislación, y el poder ejecutivo debía ser representativo de la mayoría. Adicionalmente, otro aspecto llamativo en el caso de la democracia ateniense, y en lo cual parece ser muy superior a sistemas que se reclaman de una supuesta tradición democrática en la actualidad, es, que el dinero no parecía ser un factor decisivo para "comprar" una elección. Y la propaganda con fines políticos, que hoy se ha convertido en una onerosa, poderosa e impersonal maquinaria para forjar la "opinión pública", se remitía a comediantes que ejercían con gran talento la sátira política en los anfiteatros de la época.

El surgimiento de la democracia ateniense fue un proceso gradual, a través de tres etapas reformistas en el terreno jurídico-político. En el año 594 a. C. el poeta y jurista Solón (638 a. C. - 558 a. C.) formuló la primera constitución, que otorgaba al pueblo derecho al voto unipersonal y directo, y aunque los historiadores discrepan al respecto, la mayoría concuerda en que, con este paso, se inicia en forma efectiva la democracia en la antigua Grecia. Pero el reformismo de Solón era sobre todo en el ámbito socioeconómico, para aliviar las circunstancias del campesinado griego, agobiado por las deudas y los impuestos, aunque tuvo la afortunada y audaz idea de eliminar el sistema hereditario de poder político por linajes. Sin embargo, la constitución de Solón fue abolida por la subsiguiente dictadura moderada, benévola y popular de Pisístrato (c. 607 a. C. -527 a. C.), y no sería sino hasta el ascenso político de Clístenes (570 a. C. -507 a. C.) en el año de 509 a. C., que se reestablecerían, de manera estable y perdurable, las instituciones democráticas en Atenas. Clístenes, además, impulsaría una iniciativa clave para el posterior desarrollo del humanismo en la era de los sofistas: la noción de que el nuevo Estado democrático ateniense debía nacer de la llamada isonomía, o igualdad universal e inalienable de los ciudadanos ante la ley. ${ }^{7}$ Tiempo después, Efialtes de Atenas (¿? a. C.-461 a. C.)

7 Concepción que siglos después sería retomada y ampliada por la Revolución americana y la Revolución francesa. 
un viejo y sagaz político ateniense, se atrevió a ir con toda su fuerza y prestigio en contra de la muy conservadora y resentida oligarquía ateniense. Efialtes radicalizó aún más la democracia ateniense, y sería asesinado por sus enemigos oligarcas en el año 461 a. C., siendo reemplazado por el más grande de todos los demócratas progresistas atenienses, el famoso Pericles, amigo y protector de Protágoras y los sofistas (Hignett, 1962).

Ya podemos apreciar, incluso en las pocas páginas anteriores sobre la sociedad griega de la época de Protágoras, que se trataba de un sistema de grandes contrastes, de claro-oscuros dramáticos, pero incluso así, constituía un terreno fértil y generoso para que las nuevas ideas humanistas que reivindicaban la centralidad de la capacidad humana innata para la auto-emancipación, fuesen de gran influencia. En la cúspide de una sociedad piramidal, sostenida sobre jerarquías muy verticales y asimétricas, prosperaba una casta superior constituida por ciudadanos griegos libres, que gozaban de bastantes derechos igualitarios (Figura No. 1).

\section{Figura No. 1}

\section{Pirámide social ateniense de la época de Pericles}

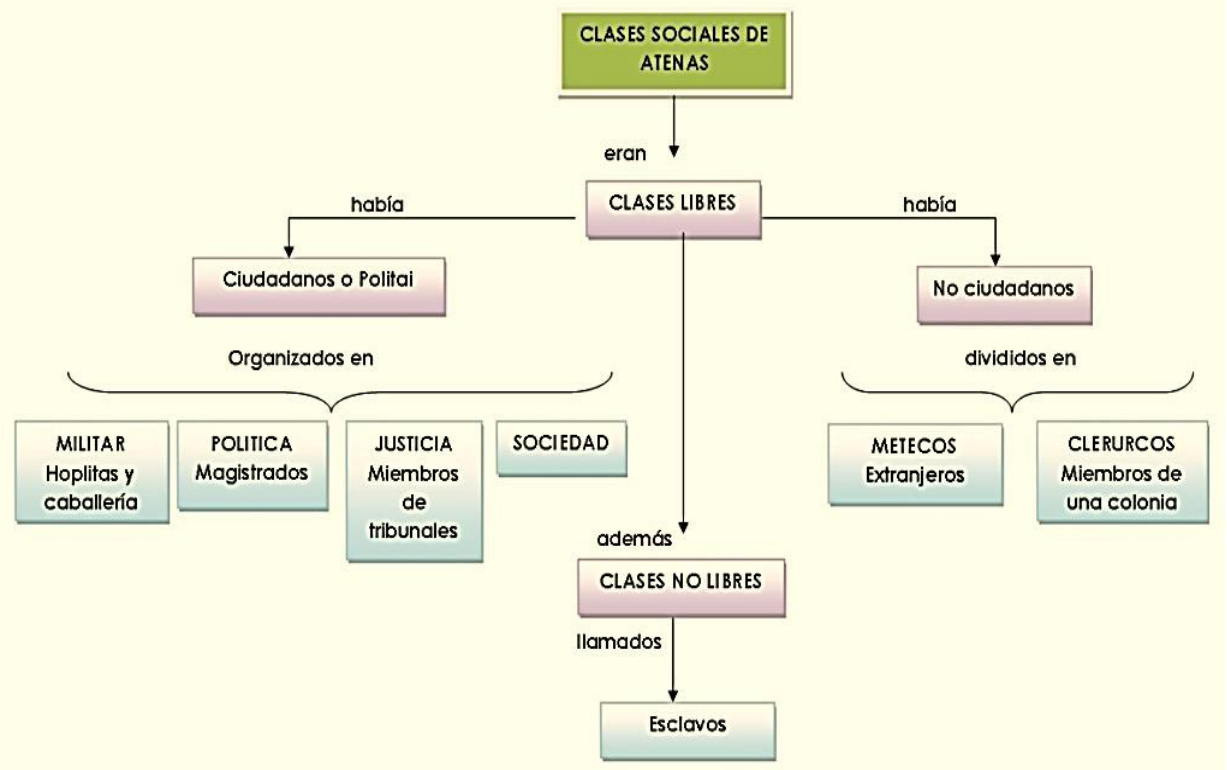

Fuente: Las tres clases sociales de la Antigua Grecia.

https://www.egrecia.es/blog/las-clases-sociales-en-la-antigua-grecia/ 
La figura anterior nos muestra las principales clases y estamentos sociales, pero no muestra la aguda elevada pirámide que era la sociedad ateniense, con una pequeña cúspide privilegiada y una gran masa humana de personas con muy escasos derechos igualitarios (como las mujeres, por ejemplo), y la enorme base esclavizada, invisible, amorfa y desposeída de cualquier derecho humano que hoy pudiéramos considerar de importancia. Y tampoco muestra la generalizada opresión y sistemática marginalización de la mujer en todos los niveles de la sociedad: misma que empeora de arriba hacia abajo en la medida que la pirámide se acerca a su amplia base esclavizada.

\section{Protágoras y los sofistas}

Protágoras de Abdera llegó caminando desde su lejano terruño a Atenas, atraído, sin dudas, por el resplandor de la gran polis. Era un hombre joven que no tenía los 25 años, muy inteligente, dotado de gran facilidad de palabra, y movido por los ímpetus de una ambición juvenil llena de optimismo. Y su ambición parecía realista, ante un nuevo mundo cultural y político se forjaba y afianzaba en Atenas, cuyas afincadas tradiciones conservadoras y oligárquicas apoyadas en los privilegios de clase (Gabba, 1988), una religiosidad dogmática, fatalista, políticamente autoritaria, era desplazada del corazón de la vida de la polis, hacia los márgenes del resentimiento y el revanchismo, por una nueva fe en la capacidad autónoma del ser humano para dirimir y dirigir los asuntos humanos, nacida a su vez del ejercicio de la razón y del poder de la voluntad. El espíritu del demos en acción, del pueblo libre (es decir, la capa superior solamente de la sociedad ateniense clásica) tomando las riendas de su destino mediante el ejercicio universal del voto directo, ya estaba fuertemente arraigado en la mente colectiva de los atenienses cuando Protágoras llega a la ciudad-Estado. No era un asunto zanjado en forma definitiva, pero si es ya una convicción predominante (Gil Fernández, 1989). Y es natural que, en esa atmósfera, Pericles hiciera su entrada triunfal y duradera, siendo el líder democrático y progresista que más tiempo se sostuvo en el poder en la Atenas clásica.

Y es evidente que ninguna propuesta democrática puede ser algo más que demagogia, si no se erige sobre los cimientos de un cierto igualitarismo entre pares, comenzando por equidad ante la ley, pero también con un cierto nivel de igualdad de oportunidades. Y para los individuos, ciudadanos plenos y libertos de Atenas, ambas aristas, cargadas de elevado potencial conflictivo, estaban más o menos bien cauteladas en la época que nos ocupa. Pero, en parte, esa unidad se sustentaba en una percepción de singularidad y superioridad intrínseca del pueblo ateniense. Había entre ellos una fuerte creencia en la pureza y autoctonía de su "raza", y de esta visión etnocéntrica, que con facilidad viraba a la xenofobia, se derivaba la firme 
convicción de que el régimen democrático, con un sistema igualitario de libertades y también de igualdad ante la ley, únicamente era viable para un pueblo que al igual que el ateniense uniera en un solo tronco la pureza de una casta superior y la continuidad del linaje sostenidas durante siglos, sin mezcla alguna con elementos foráneos y, por ende inferiores (Gil Fernández, 2005)

De todo lo anterior se desprende que cuando comienzan a surgir los sofistas en Atenas, todos los elementos fundamentales para el desarrollo de la propuesta humanista que alcanzan su plena madurez con Protágoras y los sofistas. En forma difusa y segmentada, la noción del protagonismo central del ser humano en forjar su propio derrotero en la vida, la superioridad de la racionalidad humana por sobre la fe y el misticismo trágico y fatalista ${ }^{8}$ para entender los fenómenos del mundo natural, ${ }^{9}$ la igualdad esencial de todos los individuos, ${ }^{10}$ y la equidad universal de derechos ante la ley, y participación libre, con la previsión de que en el proceso electoral directo era solo un voto per-cápita. ${ }^{11}$

En cuanto a la superioridad del razonamiento humano por sobre el misticismo religioso para entender el mundo natural, el propio Protágoras, citado y parafraseado por Filóstrato (c. $160 / 170$ a. C. - c. 249 a.C.) y también por Hesiquio (siglo IV a. C.), habría dicho:

Acerca de los dioses no puedo saber ni si existen ni si no existen ni cuál es la forma esencial que tienen: muchas son, en efecto, las cosas que impiden el conocer esto, no solamente su propia oscuridad sino también el hecho de que la vida del hombre es breve. (Cappeletti, 1982: 2)

Una noción esta última, que iría a contrapelo de la ideología propia del orden cultural oligárquico, intensamente religioso-ritualista y conservador, que precedió y siguió al siglo de Pericles (Cappeletti, 1982).

El etnocentrismo de la Grecia clásica que hemos comentado con anterioridad, y que, entre otros aspectos, delimitaba una noción muy excluyente y elitista de lo que era su sistema democrático, no siempre obtuvo aceptación intelectual y filosófica perfectamente consensuada. Y hay numerosas expresiones de ello, pero creemos ilustrativo al respecto, esta frase de Antifonte (c. 480 a. C. -411 a. C.), ${ }^{12}$

8 Lo que trasunta de los textos mismos de la famosa tragedia griega en el teatro helénico que sometía inclusive a las deidades a un poder superior concebido simplemente como "el destino".

9 Este agnosticismo que caracterizaba a los sofistas en general era bien aceptado, y posiblemente compartido, por Pericles y el círculo gobernante que lo rodeaba.

10 Con todas las enormes y dramáticas cortapisas que ya hemos discutido en este mismo ensayo.

11 Y no existían los llamados "grandes electores".

12 Contemporáneo de Sócrates. 
el más grande orador sofista: "Respetamos y veneramos a los que son de padres nobles, y no respetamos ni veneramos a los que no son de noble casa. En esto nos tratamos unos a otros como bárbaros, puesto que por naturaleza somos todos de igual manera en todo, bárbaros y griegos" (Ramírez, 2000: 22).

La cita anterior pone de manifiesto el carácter contestatario de muchas de las ideas de los sofistas en el terreno de la filosofía pragmática y sociopolítica, y por las cuales serían eventualmente perseguidos por los nuevos poderes atenienses luego del fallecimiento de Pericles. La reacción conservadora comenzó, luego de la desaparición del brillante estadista, por barrer todas las reformas e ideas sofistas, e incluso posteriormente, el gran Sócrates bebería la cicuta del revanchismo oligárquico. El humanismo, cuando ha sido genuino en su proclama de la igualdad y la libertad, impulsando la autoemacipación permanente de la humanidad, ha sido infaliblemente perseguido. Tarde o temprano, el humanismo consecuente se torna intolerable para los sistemas de dominación existentes: ¿Pues cómo aceptar a quien enarbola con fuego y pasión ideales igualitarios y glorifica el pensamiento y la acción para plasmarlos en la vida social concreta de una época particular, si lo que se detenta son privilegios elitistas y minoritarios?

Entronizarse en el núcleo dinámico de la vida cultural y el pensamiento filosófico y político de la Atenas de Pericles no fue mayor problema para los sofistas, por las varias razones que hemos esgrimido. Y lo hicieron con gran éxito intelectual y material, enriqueciéndose a medida que su popularidad y fama se imponía sin mayores barreras. Pero fue una vía de doble sentido, una relación dialéctica entre polis e intelectualidad filosófica, y sin esta relación dual, es casi seguro que la era dorada de Pericles no habría brillado con tanta intensidad, ni su luz se hubiera extendido hasta nosotros a través de largos veinticinco siglos.

Y fue así como los sofistas fueron moldeados por la atmosfera general de la vida cultural y política de Atenas, al tiempo que ellos también le dieron una radicalidad, un sello peculiar, y una precisión humanista de la que aún carecía; los sofistas fueron obviamente individuos de su época, pero ellos también catalizaron y cristalizaron ideales aún vagos y dispersos, aglutinándolos en un corpus y una praxis, que los transmutó en una agenda de trabajo progresista y reformista-radical, con resultados muy tangibles y profundos en la vida cotidiana de los ciudadanos de aquel entonces. No es filosofía selecta para la crema y nata de la intelectualidad. El humanismo nació, ante todo, como un programa mundano para el hombre común: y esa es la magia imperecedera del gran giro humanista. 
Y sería el propio Pericles, también uno de los grandes oradores sofistas, quien expresaría en su "Discurso fúnebre" (431 a. C.), según se documenta en la obra retrospectiva del historiador griego clásico Tucídides (460 a. C. - ¿396 a. C.?):

Disfrutamos de un régimen político que no imita las leyes de los vecinos; más que imitadores de otros, en efecto, nosotros mismos servimos de modelo para algunos. En cuanto al nombre, puesto que la administración se ejerce en favor de la mayoría, y no de unos pocos, a este régimen se lo ha llamado democracia; respecto a las leyes, todos gozan de iguales derechos en la defensa de sus intereses particulares; en lo relativo a los honores, cualquiera que se distinga en algún aspecto puede acceder a los cargos públicos, pues se lo elige más por sus méritos que por su categoría social; y tampoco al que es pobre, por su parte, su oscura posición le impide prestar sus servicios a la patria, si es que tiene la posibilidad de hacerlo. (Tucídides, 439 a. C. -429 a. C.)

Y creemos que este testimonio escrito y recabado por Tucídides, es confiable. Se trataba de un importante pensador e investigador dentro del campo de los sofistas, siendo otro ejemplo de los brillantes intelectuales que florecieron por doquier en la Grecia clásica, y que guiaban su trabajo científico en acorde a los principios de racionalidad metódica y naturalista del humanismo así planteados desde sus orígenes helénicos. Sus relatos historiográficos se ajustan a rigurosos estándares de recopilación de evidencias empíricas, y examinadas estas, a la luz de causas y consecuencias, sin la menor alusión a caprichosas intervenciones divinas.

En el párrafo de Pericles, citado por el historiador Tucídides, nos llama la atención el gran contraste que su entendimiento de la democracia tenía, en relación con el cascarón político e institucional de nuestros días, por lo general vacío de verdadera sustancia democrática. Pericles afirma que es un sistema en el que "la administración se ejerce en favor de la mayoría, y no de unos pocos", lo que solo en excepcionales circunstancias es el caso con nuestras "democracias" contemporáneas, donde minorías elegidas por alguna mayoría, ejercen el poder únicamente para favorecer los intereses de pequeños grupos elitistas y dominantes de la política y la economía. De manera que, a pesar de erigirse dentro de un sistema social atrozmente desigual en los tres aspectos fundamentales de clase, género y etnicidad, la democracia ateniense tenía, no obstante, una cierta esencia igualitaria $\mathrm{y}$, por ende, humanista, de la que carecen casi todas nuestras seudo democracias en el capitalismo avanzado del siglo XXI.

La incursión de los sofistas, liderados en esto por Protágoras, en el campo de la filosofía jurídica, comienza con el fuerte ataque a un Estado y sistema político regido por una concepción bastante primitiva de la llamada phisis o fisis (entendida 
en ese momento como el poder "natural" del caudillo, el líder, en tanto individuo particular, que puede llegar incluso a ser un tirano) y no estrictamente por el nomos (las leyes, las normas establecidas, etc.); y a ello se agrega ese nuevo énfasis que ellos le imprimieron a la temática, exaltando el principio de igualdad entre las personas. Estos sellos distintivos de la nueva filosofía política de la sofistería, es lo que hoy se llama en jurisprudencia como la perspectiva iusnaturalista. Y esto último significa que, en realidad lo que los sofistas hicieron en este terreno, fue cambiar el orden y el contenido de las nociones de fisis y nomos: entendieron el primer concepto como el derecho natural inherente ${ }^{13}$ a la condición humana de todo individuo (y no como el poder unipersonal y por encima de la ley o el nomos, del caudillo, o la divinidad que lo respalda al ungirlo como su representante en la tierra), y del cual se deriva el nomos, o la norma, sustentada así en los derechos naturales y esenciales del ser humano y sancionada en forma explícita de ley: iusnaturalismo (Sealey, 1994).

Para esclarecer y ampliar más sobre esta distinción entre fisis y nomos, podemos citar al respecto este párrafo de Javier H. Barbieri:

Nomos deriva de la misma raíz del verbo nemo, que significa (en voz activa) "atribuir", "repartir según el uso o la conveniencia", y (en voz media) "tener su parte", "usar la parte atribuida", "creer", "reconocer como verdadero"2. Así, el sustantivo nomós, en su primera acepción, significa "lugar repartido, dividido en parcelas", "campo de pastoreo". Y nomos - solo modificando el acento- designa una "regla", "uso", "costumbre". Así pues, de la actividad de repartir la tierra en partes no marcadas por la naturaleza (physis), es decir, no delimitada por accidentes naturales, deriva el concepto que se identifica con convención humana (nomos). La división de la tierra puede, entonces, ser natural (i.e., según physis) o convencional (i.e, según nomos). La primera es obra divina y la segunda, arte humano.

A su vez, la palabra physis, cuyo concepto es - como sabemos- el punto de partida de toda la filosofía presocrática, deriva del verbo phyo que (en voz activa) quiere decir "brotar", "hacer salir", "hacer crecer", y phyomai (en voz media y pasiva), que significa "nacer", "crecer", "haber nacido en tal o cual condición, con tal o cual disposición o cualidad", "ser tal o cual por condición", "tener tal o cual condición (natural)"3. Los latinos tradujeron el término physis por natura, en concordancia etimológica perfecta, pues este sustantivo procede del verbo nascor, "nacer", "formarse", "ser puesto en el mundo"4. Así, el término physis lleva en su significado no solo la idea de "lo que es originaria y fundamentalmente", sino también la noción del "proceso por el cual lo originario se despliega en lo múltiple"5.

13 E inalienable, se agregaría en el Siglo de las Luces, como propiedad sustancial de la naturaleza humana. 
De esta manera, nomos se identifica con lo artificial y physis con lo natural. El nomos exige, pues, un sujeto activo que dispensa o reparte lo que da la naturaleza, una mente de la que emane la norma distributiva y, a la vez, un sujeto pasivo que la reciba. (Barbieri, 2011: 3)

Este cambio de horizonte filosófico-político en la concepción de fisis y nomos y la relación entre ambos en el pensamiento de la sofística, es reorientado metafóricamente por lo que los artistas plásticos llaman "punto de fuga"; es decir, un nuevo horizonte con su nueva perspectiva "de fuga", y que apunta en otra dirección distinta a la tradicional y predominante hasta entonces, en cuanto a la vida política se refiere, así como a su fundamentación filosófica. Es una nueva visión en la que los sofistas aparecen como los primeros apologistas de la democracia, entendida como debate permanente de ideas. Se plantea la vida política en la polis como un espacio de ineludibles contradicciones y tensiones, donde los actores (los humanos de carne y hueso como los llama Unamuno), conviven, debaten y luchan entre sí. Los sofistas abandonan, de esta forma, la reflexión abstracta sobre la naturaleza y el fisis político, entendido en su sentido más elemental (la presencia corpórea del líder omnipotente, ya sea monarca o caudillo, o el poder omnímodo de la divinidad), para reflexionar sobre el nomos, pero concebido como la ley que emana y se legitima a partir de la naturaleza humana universal y esencial, y no del individuo autocrático en la cúspide del poder, legitimado por voluntad divina y sobrehumana (Romilly, 1997). Y todo este planteamiento sofístico, en ruptura y en oposición con el ideal de polis, vida cívica y hombre ateniense que prescribía la concepción tradicional de tipo heroico y aristocrático, inmortalizado por los principales poemas épicos griegos de La Ilíada y La Odisea, atribuidas al genial dramaturgo Homero (c. s. VIII a. C.) (Jaeger, 2001).

En la narrativa de Homero se trasunta una vida social dirigida por caudillos con fuerte orientación bélica y territorial, y subdividida en varias regiones cada una con un líder militar y político que poseía una autoridad superior transferida de una generación a otra en forma hereditaria. Los caudillos se rodeaban de un séquito inmediato constituido por individuos de probada lealtad. Estos seguidores incondicionales, disfrutaban de pingues privilegios, sobre todo en la repartición de los botines y con vastas propiedades. Esa suerte de corte que rodeaba al líder, tenían un matrimonio con una sola mujer, pero no eran monógamos puesto que podían tener numerosas concubinas. Un consejo dirigido por el caudillo regional junto con su consejo cercano, tomaban las decisiones principales y luego en asamblea las transmitían al pueblo; era fisis en su versión más primitiva: dominio "natural" mediante la fuerza bruta (Dalby, 2008). Esta tradición sería completamente ajena a la visión de los sofistas, quienes por el contrario exaltan la figura primordial del ciudadano común. 
La concepción de la democracia como movimiento perpetuo de ideas en contradicción, convierte a los sofistas en discípulos de Heráclito, primer filósofo de la dialéctica ${ }^{14} \mathrm{y}$ el pensador griego antiguo más admirado por Marx, $\mathrm{y}$, al menos en este aspecto, en particular, nos atrevemos a afirmar que el relativismo sofista, a ultranza, adquiere cierta validez. Si bien, hemos tomado distancia con el postulado relativista de los sofistas en pasajes anteriores de este mismo ensayo, pues niega la posibilidad de establecer leyes y principios universales para entender el movimiento y la dinámica de la materia, queremos rectificar un poco esa aserción; al destacar aquí también, que sin la idea de que todo está en movimiento perpetuo impulsado por las contradicciones internas en cada nivel fenomenológico de la existencia y del universo, no podríamos entender que la unidad de los contrarios y su solución en la síntesis, es la expresión paradójica de las leyes mismas, de la realidad.

Como era de esperarse, en un movimiento filosófico inclinado más que nada hacia el pragmatismo del "éxito" (entendido como el accionar virtuoso en función de ciertos ideales, para alcanzar influencia, fama y fortuna) y la filosofía política, el lenguaje, su estudio y su uso, acorde con elevados estándares de retórica al servicio de la persuasión efectiva, ocupaba un lugar preeminente en sus reflexiones y acciones. Quizá fueron los primeros dentro del desarrollo de la filosofía especulativa y precientífica, en postular de manera tan enfática y explícita cómo se podía forjar y manipular la opinión pública y las percepciones colectivas, mediante el uso, efectivo e incluso artero, de la retórica. Era el reconocimiento precoz de esa gran y única habilidad humana en el mundo natural, que es nuestra capacidad innata y cultural para el extraordinario desarrollo del potencial lingüístico. Siglos después, otro gran humanista, Wilhelm von Humboldt (1767-1835), para quien el lenguaje es la clave de la naturaleza humana, escribió en sus propias palabras decimonónicas: “(...) puesto que el ánima humana es la cuna, patria y hogar del lenguaje, así van desconocidas y ocultas todas sus propiedades a parar a lo mismo." (Martí Marco, 2012: 56).

A medida que la sofística gana terreno en la vida intelectual y política de Atenas, el espíritu mundano y superficialmente religioso de la polis se hacía más notorio. Sin mayores tapujos, Trasímaco (c. 459 a. C.- 400 a. C.), uno de los numerosos sofistas destacados, habría llegado incluso a afirmar que "Los dioses no ven los asuntos humanos; de lo contrario no descuidarían el mayor de los bienes humanos, la justicia: vemos, en efecto, que los dioses no la practican" (Romilly, 1997, p. 67). El agnosticismo sofista se pone de manifiesto en todas sus actividades, y sobre todo, en su producción intelectual; creando, de tal forma, en conjunción

14 Posiblemente algo posterior, o en contemporaneidad con el filósofo chino Lao-Tse (China, siglo VI a. C.), autor del famoso libro sobre la unión y síntesis de los contrarios, titulado Tao Te Ching (Fowler, 2005). 
con la atmósfera política prevalente en la época, condiciones muy propicias para considerar la praxis humana como sobredeterminante en la comprensión de los "asuntos estrictamente humanos"; así como en la capacidad de estos mismos para formar y reformar la vida social acorde con lo que se considerase más conveniente al perfeccionamiento constante del bien común. El humanismo, con su propuesta esencial, que colocaba en el centro de la vida social al protagonismo humano por encima de cualquier otra fuerza exterior a su naturaleza y poseedora de atributos sobrenaturales, marcaría así el período más progresista y liberal en la historia del período helénico clásico.

Luego del ocaso de la sofistería, Sócrates sería, en comparación al conservadurismo de Platón y de su discípulo Aristóteles, el último gran progresista y humanista, luego de la muerte de Pericles (Colaiaco, 2013). Pues considerando que casi todo lo que sabemos de Sócrates -quien nunca escribió algún texto que legara a la posteridad- viene del muy conservador Platón, pero su condena a muerte por parte de los poderes atenienses de entonces, por su idea de que el ser humano tenía un espíritu propio con "una existencia etérea sin el consentimiento de ningún dios como figura explícita", lo muestra, a nuestro juicio, como un pensador que concebía a la humanidad como una entidad no sujeta a los arbitrios de un orden divino y sobrehumano. Y sería perseguido por ello, al igual que Protágoras, al compartir, en sus propios términos, una postura similar en tanto libre pensador y crítico de los dogmas religiosos establecidos.

Muy pronto los sofistas descubrieron que sus clases, consistentes en debates y conversaciones abiertas y más o menos improvisadas, podían redundar en un beneficio pecuniario para ellos, considerando la popularidad y demanda que se generó en relación con sus enseñanzas. Los sofistas, como bien señala Romilly (1997), eran, ante todo. profesores y se concebían, a sí mismos, como "profesionales de la inteligencia". El propio Trasímaco, hizo inscribir sobre su lápida: "Mi patria era Calcedonia y mi profesión el saber". Las enseñanzas de los sofistas no eran clases formales e informativas con una transmisión de saberes ya acopiados, sino más bien instructores sofisticados y de gran vuelo intelectual sobre temas prácticos. En sus seminarios asesoraban a quienes quisieran dedicarse a la política -o estuviesen ya inmersos en ella y desearan perfeccionar sus habilidades- y necesitaban conocer la administración del Estado, y los secretos técnicos de una retórica efectiva que les permitiera argumentar y vencer en los debates públicos.

Para poder darse una idea más precisa de lo que usualmente podía devengar un sofista, hay que ponerlo en perspectiva comparativa: un juez profesional en la 
ciudad de Atenas devengaba una paga mensual de medio $\mathrm{dracma},{ }^{15}$ mientras que algún sofista, de reputación, podía llegar a ganar veinte dracmas por una sola lección. Pero un maestro sofista, de elevado reconocimiento, como Protágoras, podía obtener un estipendio de hasta diez mil dracmas por lección, aunque muchas veces el pago por el seminario podía variar acorde con negociaciones sobre su costo con los propios estudiantes (Platón, 2007: 156-157).

Con el triunfo en Atenas de la restauración conservadora, después del fallecimiento de Pericles, esta orientación de los sofistas al lucro material obtenido con su prestigio y talento intelectual -y que hoy es tan común entre la intelectualidad contemporánea- se prestó, entre otras líneas de ataque, para que Platón y otros filósofos posteriores, procedieran a demoler la reputación de los sofistas, dejando un estereotipo derogatorio que persiste hasta nuestros días. "Bajo el régimen de escritura platónica de la historia de la filosofía, los sofistas pagan desde hace veinticinco siglos el considerable tributo de una mala reputación y de una definición equivocada" (Onfray, 2007: 89).

El nivel de desprestigio ignorante ${ }^{16}$ que rodea con un aura negativa a los sofistas, sorprende cuando se conocen mejor los resultados de su obra y la importancia muy duradera que tendría su noción fundacional del humanismo. Desde el punto de vista político y filosófico, esto es asombroso y decepcionante al mismo tiempo. Más aún cuando se considera que el origen etimológico de la palabra griega sophistés (sofistas) que significa sabios, proviene de sophós que significa sabiduría.

Pero si bien nuestro conocimiento de los textos y trabajos de los sofistas rara vez proviene de los escasos fragmentos de sus obras que han llegado hasta nosotros, con el agravante que casi todos ellos están descontextualizados y son difíciles de situar cronológicamente, al menos sabemos que eran filósofos de acción y, sobre todo, educadores incansables. El mismo Protágoras habría resaltado esta vocación pedagógica con especial orgullo:

Hago francamente profesión de enseñar a los hombres y me declaro sofista. El mejor de todos los disimulos es, a mi parecer, no valerse de ninguno; quiero más presentarme, que ser descubierto. Y afirmaré que ningún mal me ha resultado por hacer ostentación de ser sofista, a pesar de muchos años que ejerzo esta profesión,

15 Nombre que se le daba en las ciudades-Estado de la Grecia antigua, a las monedas hechas de plata que se utilizaban para los intercambios comerciales y pagos salariales.

16 Mucha de esta ignorancia resulta no solo de los ataques contra los sofistas por Platón, sino de que únicamente nos han quedado fragmentos de sus textos, que Romilly (1997: 10-11) ha estimado que no ocuparían más de veinte páginas. 
porque a mi edad podría ser el padre de todos los que están aquí. (Solana Dueso, 2013: 45)

Protágoras vivó dos etapas muy diferentes en su relación con los atenienses. Un momento de gloria, durante el cual los sofistas eran maestros principales de la polis y Protágoras era, adicionalmente, amigo cercano de Pericles. En esa fase Protágoras alcanzó el cenit de su fama y popularidad, y este ascendiente notable para un filósofo en la esfera política y en los asuntos de Estado, significó que Pericles, en el año 443 a. C., le encargara la redacción de la Constitución de la nueva colonia de Turios. En ella Protágoras vertió toda su sapiencia filosófico-pragmática, y diseñó, lo que podríamos llamar, el primer plan para un Estado benefactor, socializando el proceso de enseñanza-aprendizaje bajo el alero de la educación pública. Como pionero del humanismo en la historia de las sociedades complejas y jerárquicas, Protágoras nos muestra que esta perspectiva ético-filosófica en que se reivindica el lugar central de la condición y la razón humana en la vida social, debe estar, siempre, estrechamente asociada con sistemas sociales enraizados en la idea del bien común y la justicia social. La autoemancipación permanente de la humanidad, no es más que la búsqueda, nunca plenamente realizada, de formas de vida igualitaria cada vez más amplias y profundas.

Según afirma el importante historiador de la filosofía clásica griega Diógenes Laercio (siglo III d. C.), la situación comenzó a tornarse bastante mala para Protágoras, cuando dio lectura en casa de Eurípides, a partes de su libro titulado Sobre los dioses. En esa obra, Protágoras afirmaba que desconocía realmente la existencia o inexistencia de entidades divinas con poderes sobrehumanos. ${ }^{17}$ De acuerdo con el registro histórico realizado varios siglos más tarde por Diógenes Laercio, las palabras de Protágoras habrían sido las siguientes: "Con respecto a los dioses no puedo conocer ni si existen ni si no existen, ni cuál sea su naturaleza, porque se oponen a este conocimiento muchas cosas: la oscuridad del problema y la brevedad de la vida humana" (Circa siglo III d. C., I:(120).

Al parecer, alguno de los presentes, sobre cuya identidad no hay seguridad plena, lo acusó de "impiedad", y fue juzgado y condenado en el año 416 a. C., a que todas sus obras fueran quemadas y él debería partir al destierro, o posiblemente condenado a muerte. El cargo contra Protágoras fue de "asebia" o impiedad, que, en forma muy significativa, cabe notar fue el mismo con que Sócrates sería condenado a muerte y ejecutado treinta años después, cuando el conservadurismo de los poderes existentes en Atenas había alcanzado ribetes aún más extremos.

17 De acuerdo con algunos autores esto ocurrió alrededor del año 416 a. C., cerca de trece años después de la muerte de Pericles, cuando ya la restauración conservadora en la Grecia clásica estaba en marcha. 
Protágoras partiría al destierro ${ }^{18}$ rumbo a Sicilia, pero la nave en que viajaba naufragó y el filósofo del humanismo, fallecería ahogado a una edad que fluctúa entre 70 y 90 años, posiblemente en el año 411 a. C.

La restauración conservadora de los poderes oligárquicos, el empobrecimiento y eventual obsolescencia de la democracia, el fin de todo impulso reformista siguiendo las líneas del humanismo, la derrota de Atenas en la Guerra del Peloponeso en el año 404 a. C., el ascenso de Macedonia con Filipo II y Alejandro Magno, marcaron un acentuado declive del progresismo en la Grecia antigua. Reyes y dioses sustituyeron el protagonismo del ser humano y del ciudadano común, y la filosofía en la tradición de Platón y Aristóteles se volvió cada vez más conservadora, expresándose en enjundiosos esfuerzos filosóficos para racionalizar y naturalizar graves desigualdades sociales, como la esclavitud y la supuesta inferioridad biológica de las mujeres.

\section{La rama dorada}

El primer brote fundacional del humanismo sentó las bases futuras de una perspectiva ético-filosófica que, en adelante, tendría varios avatares, altos y bajos, momentos cruciales de auge y caída, y que, a lo largo de esos meandros se abriría paso durante dos milenios y medio, para llegar hasta nuestros días. ¿En qué consiste el poder de duración y resiliencia histórica de una propuesta que muchos ignoran, ${ }^{19} \mathrm{y}$ que sigue plenamente vigente para quienes se interesen, de verdad, en su esencia real?

Durante esos dos mil quinientos años, la idea central y fundacional del humanismo se mantendría incólume, a pesar de los prolongados hiatos de olvido e intensos períodos de persecución, y rebrotaría, en cinco instancias históricas subsecuentes, que se produjeron en grandes brotes de praxis humanista: 1. El segundo brote: humanismo de la Edad de Oro Islámica (s. VIII d. C. - s. XIII d. C.); 2. El tercer brote: humanismo del Renacimiento europeo (s. XV d. C. -s. XVI d. C.); 3. El cuarto brote: humanismo liberal del Siglo de las Luces (s. XVII d. C.); 4. El quinto brote: humanismo socialista (fines s. XVIII-s. XIX). A cada uno de estos brotes dedicaremos en el futuro un ensayo específico, para posteriormente, en otro ensayo final, abordar el tema de la posibilidad de un sexto brote, al que llamamos Nuevo Humanismo. Cada uno de estos brotes tendría rasgos peculiares y estaría integrado por numerosas escuelas, vertientes, variaciones según autores y autoras, pero en todos esos brotes y sus múltiples matices, descubrimos un hilo conductor principal

18 Aunque también se piensa que lo hizo para escapar de una eventual pena de muerte (Filóstrato, 1998).

19 Incluso por parte de quienes se autoerigen como humanistas, y hablan mucho hoy del humanismo, y lo utilizan como un conveniente cliché que parece contener muchos significados irrelevantes. 
que devela tanto continuidad de solución como solución de continuidad. Y a eso es lo que llamamos la "rama dorada":

Que el ser humano, y solo el ser humano, puede ser forjador de su destino, aunque los resultados de su acción racional y consciente no sean casi nunca exactamente los que se perseguían y deseaban. Que el ser humano, y solo el ser humano, puede autoemanciparse constantemente, incluso rompiendo las cadenas de la opresión que él mismo ha creado a lo largo de su historia. Que toda emancipación solo es verdadera cuando las víctimas de una determinada forma o formas de opresión y desigualdad toman consciencia de su situación y se convierten en actores sociales protagónicos de su propia liberación. Y que una autoemancipación solo es auténtica liberación, cuando es guiada por profundas y legítimas aspiraciones igualitarias.

\section{Referencias}

Baraona, Miguel. (2013). Para un humanismo del siglo XXI: desafíos y propuestas. Revista de Nuevo Humanismo, 1(1).

Baraona, Miguel y Jaime Mora. (2017). Hacia una epistemología del Nuevo Humanismo. EUNED: San José-Costa Rica.

Barbieri, Javier. (2011). Physis frente a nomos. Dikaion. Doi: https://dikaion.unisabana. edu.co/index.php/dikaion/article/view/1948/2502

Blunden, Andy. (1956). Karl Marx’s "Confession”. Review of Social History, 10(2), 60-67.

Cappeletti, Angel J. (1982). El agnosticismo de Protágoras. Revista de Filosofía Diánoia, 28(28).

Colaiaco, James. (2013). Socrates Against Athens: Philosophy on Trial. Routledge N. Y.

Dalby, Andrew. (2008). La reinvención de Homero. Gredos: Madrid.

Fernández, Clara. (2017). La crítica al cientificismo de Miguel de Unamuno. Universidad Pontificia Icai-Icade: Madrid.

Filóstrato. (1998). Vidas de los sofistas. Editorial Gredos: Madrid.

Fowler, Jeaneane. (2005). An Introduction to the Philosophy and Religion Of Taoism: Pathways to Immortality. Sussex Academic Press: Brighton.

Gabba, Emilio. (1988). La società ateniense nel 'Vecchio Oligarca'. Athenaeum, 66: 5-10.

Garlan, Yvon. (1989). Les esclaves en Grece ancienne. La Decouverte: Paris. 
Gil, Luis. (1989). La ideología de la democracia ateniense. CFC: Estudios griegos e indoeuropeos, 23: 39-50.

Gil, Luis. (2005). Las primeras justificaciones griegas de la democracia. $C F C(G)$ : Estudios griegos e indoeuropeos, 15: 95-105.

Gutiérrez, Javier. (1999). La agonía del cientificismo. EUNSA-Astrolabio: Madrid.

Hignett, Charles. (1962). A History of the Athenian Constitution. Oxford University Press: UK.

Jaeger, Werner. (2001) Paideia: los ideales de la cultura griega. Nobleza y areté. Fondo de Cultura Económica: México.

Laercio, Diógenes. (c. s. III d. C.). Los siete sabios de Grecia. Filósofos presocráticos. Escuela Jónica. Biblioteca Clásica: Madrid.

Llanos, Alfredo. (1953). Los presocráticos y sus fragmentos. Desde los milesios hasta los sofistas del siglo V. Juárez Editor: Argentina.

López, Ricardo. (2018). Presentación de los sofistas. Los primeros maestros del pensamiento. Universidad de Chile: Chile. doi: http://decsa.med.uchile.cl/wp-content/ uploads/Sofistas.pdf

Martí, María. (2012). Wilhelm von Humboldt y la creación del sistema universitario moderno. Verbum: Madrid.

Mossé, Claude. (1991). La femme dans la Grèce Antique. Complexe: Paris.

Onfray, Michel. (2007). Las sabidurías de la antigüedad. Anagrama: Barcelona.

Platón. (2007). Obras completas. Refutaciones sofísticas. Gredos: Barcelona.

Pomeroy, Sarah. (1990). Diosas, rameras, esposas y esclavas en la antigüedad clásica. Barcelona: Akal.

Pomeroy, Sarah B. (1999). Families in Classical and Hellenistic Greece: Representations and Realities. Oxford University Press: Oxford.

Ramírez, Gerardo. (2000). La retórica de Antifonte. FCE: México.

Romilly, Jacqueline de. (1997). Los grandes sofistas en la Atenas de Pericles. Seix Barral: España.

Sealey, Raphael. (1994). The Justice of the Greeks. University of Michigan Press: Ann Arbor. 
Solana, José. (2013). Los sofistas. Testimonios y fragmentos. Alianza: Madrid.

Tucídides. (439 a.C.-429 a. C.). (1990-1992). Historia de la guerra del Peloponeso. Editorial Gredos: Madrid.

Unamuno, Miguel. (1970). Del sentimiento trágico de la vida y el hombre de carne y hueso. Editorial Akal: Madrid.

Vidal-Naquet, Pierre. (1995). Esclavage et gynécocratie dans la tradition, le mythe et l'utopie. Le chasseur noir. La Découverte: Paris.

Vidal-Naquet, Pierre. (2005). "Les femmes, les esclaves, les artisans". Le chasseur noir. La Découverte: Paris. 